\title{
The urgent need to change the current medical approach on tobacco cessation in Latin America
}

\author{
Guadalupe Ponciano-Rodríguez, MSc. ${ }^{(1)}$
}

\begin{abstract}
Ponciano-Rodríguez G. The urgent need to change the current medical approach on tobacco cessation in Latin America. Salud Publica Mex 2010;52 suppl 2:S366-S372.
\end{abstract}

\begin{abstract}
Absract
Despite of the accumulation of scientific evidence confirming the health consequences of smoking and the new paradigm of smoking as a disease where nicotine is the drug that modifies the functional and morphological characteristics of the brain in dependent smokers, tobacco smoking continues as an important public health problem in many Latin American countries. In contrast with big advances in the tobacco control area, as an example the Framework Convention on Tobacco Control signed by 168 countries, the role of health professional in the fight against tobacco is still less than ideal. In many Latin American schools of medicine, deficiencies in medical education has led to insecure physicians when they have to motivate their patients to stop smoking or to prevent young people to begin tobacco consumption. If each general practitioner or specialist during their daily medical assistance could talk to their smoker patients about the big benefits of stop smoking and support them to get free of tobacco, we would be winning a battle against smoking. Also if we could achieve generations of young non smoking doctors, who could be a real example for patients, this could also impact the prevalence of smokers. In this article we analyze the neurobiological bases of nicotine addiction, which we think are missing in the medical curriculum and could help doctors to understand tobacco smoking as a disease rather than a risk factor, and discuss the main reasons supporting an urgent change in the medical approach of tobacco cessation in Latin America as well as the need to actualize the medical curriculum in order to give physicians the skills needed to
\end{abstract}

\author{
Ponciano-Rodríguez G. \\ Urge cambiar el abordaje de la cesación del tabaquismo \\ por los médicos en América Latina. \\ Salud Publica Mex 2010;52 supl 2:S366-S372.
}

\section{Resumen}

A pesar de que actualmente contamos con una gran cantidad de evidencias científicas que confirman que el tabaquismo es una enfermedad con graves consecuencias para la salud y que la nicotina es una droga o sustancia psicoactiva que causa alteraciones funcionales y morfológicas en el sistema nervioso central de los sujetos dependientes, el consumo de tabaco continúa siendo un grave problema de salud pública en muchos países del mundo y Latinoamérica no es la excepción. En contraste con grandes avances en el área de control del tabaco, por ejemplo la firma del Convenio Marco para el Control del Tabaco por 168 países, el papel de los profesionales de la salud en la lucha contra el tabaquismo todavía dista mucho de ser lo ideal. En las escuelas de medicina de muchos países de América Latina se ha descuidado la educación de los futuros médicos para que durante el desempeño de sus actividades cotidianas sean piezas clave en la lucha contra el tabaquismo, motivando a todos sus pacientes a dejar de fumar y en la prevención de esta adicción. Si durante cada consulta el médico general o especialista interviniera con sus pacientes fumadores hablándoles de todos los beneficios que trae la cesación del tabaquismo y los apoyara a dejarlo, se estaría ganando una gran batalla en la lucha contra el tabaquismo. Asimismo, si logramos que los futuros médicos no fumen y realmente sean un ejemplo para sus pacientes, esto también redundaría en una menor prevalencia de fumadores. En este artículo se realiza una revisión de las bases neurobiológicas de la adicción a la nicotina, aspecto faltante en el currículo de la carrera de medicina que ayudaría a los futuros médicos a

(I) Clínica para el Tratamiento del Tabaquismo. Facultad de Medicina, UNAM. México DF, México.

Received on: May 25, 2010 - Accepted on: July 13, 2010

Address reprint requests to: Guadalupe Ponciano Rodríguez. Clínica para el Tratamiento del Tabaquismo. Facultad de Medicina, UNAM. Circuito Interior de Ciudad Universitaria, Col. Coyoacán. 045I0 México, DF, México.

E-mail:ponciano@servidor.unam.mx, sinfumar@mexico.com 
intervene successfully with their smoker patients and to be themselves non smokers.

Key words: tobacco smoking; cessation; prevention; medical education; schools of medicine; Latin America; curriculo entender el nuevo paradigma del tabaquismo como enfermedad y no como factor de riego, y se discuten los principales argumentos que sustentan la urgencia de un cambio en el abordaje del tabaquismo por los médicos en Latinoamérica, así como la necesidad de actualizar los planes de estudio de las escuelas de medicina para formar médicos no fumadores capaces de realizar intervenciones exitosas en sus pacientes fumadores.

Palabras clave: tabaquismo; cesación; prevención; educación médica; escuelas de medicina; Latinoamérica; currículo
The role and image of the health professional are essential in promoting tobacco-free lifestyles and cultures. WHO, 2005.

$\mathrm{I}^{\mathrm{n}}$ n 1992, smoking prevalence had risen to 50 percent or more among young people in some urban areas of Latin America and the Caribbean and was increasing among women. "Devastating health consequences can result if current smoking prevalence is not curtailed in the Americas. Coordinated campaigns must be launched because progress toward a smoke-free society requires regional coordination," Dr. Antonia Novello said in March 12, 1992 during the release of "Smoking and Health in the Americas", the first Surgeon General report that predicted an epidemic of smoking-related disease and death in Latin America. ${ }^{1}$ Many events have occurred since that time, in addition to the worldwide recognition of smoking as the leading cause of preventable death, ${ }^{2}$ the new paradigm about smoking accepted that it is an addiction. Currently we have new pharmacoterapies available and different behavioral and psychological approaches to treat nicotine addiction.

The World Health Organization through the International Statistical Classification of Diseases and Related Health Problems (ICD-10), ${ }^{3}$ and the American Psychiatric Association through the DSM-IV-TR since $1980^{4}$ included tobacco dependence as a substance abuse disorder and tobacco withdrawal as an organic mental disorder and established the criteria to recognize it. The report of the General Surgeon (1988) recognized that cigarettes and other forms of tobacco are addicting, nicotine is the drug in tobacco that causes addiction and the pharmacologic and behavioral processes that determine tobacco addiction are similar to those that determine addiction to drugs such as amphetamines, alcohol, heroin and cocaine. ${ }^{5}$

Nearly 5 decades of research linking tobacco use to health impairment would appear to be enough to eradicate tobacco smoking from earth. However, there are 1.25 billion smokers worldwide, and this number is increasing every year, mainly among adolescents and children. Though the prevalence of smoking has declined in some developed countries, the rate of decline has been slow and the rate is increasing in developing countries, including those in Asia and Latin America. The training and involvement of physicians in the treatment of nicotine addiction has not received the recognition and attention it deserves. This is one of the primary challenges of Medicine today.

This article focuses in the last concept. Although doctors played a extremely important role in the definition of the health consequences of smoking, the general perception is that treatment for nicotine addiction is not a medical problem; however, medical evidence shows that cigarette smoking is addictive, and that nicotine dependence is not only a disease itself but also a risk factor for more than 25 diseases.

\section{Addiction and tobacco}

Addiction to nicotine is a chronic, relapsing, and, in many cases, lifelong problem that is likely to need repeated interventions to achieve long-term abstinence. Nicotine addiction is the most common chronic disorder in the developed world. Doctors must understand this idea. ${ }^{6}$ Probably one reason for this lack of understanding is that the neurochemical bases of nicotine addiction are not widely reviewed in Medicine schools. ${ }^{7}$

Nicotine acts as an agonist at brain nicotinic receptors, for which the endogenous neurotransmitter is acetylcholine. Each nicotinic receptor consists of five subunits, which form a central cation $(\mathrm{Ca}++, \mathrm{K}+$, $\mathrm{Na}+$ ) channel. ${ }^{8}$ Many subtypes of nicotinic receptors are widely distributed throughout the central nervous system but the most important for the addictive process are the $\alpha_{4} \beta_{2}$ nicotinic receptors, located at the ventral tegmental area where a dense supply of dopamine neurons is linked to the brain's main 'reward centre', the nucleus 
accumbens. The effects of $\alpha_{4}$-receptor activation have been shown to be important in dependence, including reinforcement, tolerance and sensitization. The $\alpha_{4} \beta_{2}$ receptor also has the highest sensitivity to nicotine $-50 \%$ of its maximal activation is produced at a concentration $\left(\mathrm{EC}_{50}\right)$ of $0.1-1.0 \mathrm{mM}$, but it can be desensitized by lower concentrations. ${ }^{9}$

Considerable evidence suggests that repeated nicotine exposure results in an increase in functional nicotinic receptors in the brain. Autoradiography studies of smokers' brains have revealed marked increases of 300 to $400 \%$ of these receptors in all cortical regions. ${ }^{10}$ Such increases sensitize the mesolimbic dopamine response to nicotine. ${ }^{11}$ This dopamine response (i.e. an increase in extra-synaptic dopamine in the extracellular space between fibers in the accumbens) appears to be associated with the reinforcing and addictive properties of nicotine and other drugs like cocaine and amphetamine. ${ }^{12}$ This response confers hedonic properties on behaviors associated with dopamine activation. Over time and with repeated exposures, the smoking ritual (e.g. opening the pack, lighting the cigarette, feeling the smoke hit the back of the throat) becomes capable of stimulating mesolimbic dopamine and thereby acts as a reinforcer itself, even in the absence of agonist(nicotine)-stimulated dopamine activation. ${ }^{11,13,14}$ This may be the reason why smokers often state that they enjoy the ritual of smoking.

Also the frontal cortex is involved in various aspects of drug addiction, including reinforcing responses to drugs during intoxication, activation during craving, and deactivation during withdrawal. The involvement of the frontal cortex throughout these cyclical stages of addiction is likely to play an important role in the cognitive, behavioral, and emotional changes that perpetuate drug self administration. As such, nicotine has cognitive-enhancing, attention-gating, stress-alleviating, and weight-regulating effects that may contribute to tobacco dependence. ${ }^{11}$

Habitual nicotine use through smoking cigarettes causes dependence and increased tolerance according to the definition of the International Statistical Classification of Diseases and Related Problems (ICD10) of the World Health Organization in its 10th revision. ICD10 defines dependence as a cluster of behavioural, cognitive, and physiological phenomena that develop after repeated substance use and that typically include a strong desire to take the drug, difficulties in controlling its use, persisting in its use despite harmful consequences, a higher priority given to drug use than to other activities and obligations, increased tolerance, and sometimes a physical withdrawal state. The dependence syndrome may be present for a specific psychoactive substance (e.g. tobacco, alcohol, or diazepam), for a class of substances (e.g. opioid drugs), or for a wider range of pharmacologically different psychoactive substances. ${ }^{3}$ Regarding the withdrawal state, this is a group of symptoms of variable clustering and severity occurring on absolute or relative withdrawal of a psychoactive substance after persistent use of that substance. The onset and course of the withdrawal state are time-limited and are related to the type of psychoactive substance and dose being used immediately before cessation or reduction of use. ${ }^{15}$

According to the Diagnostic and Statistical Manual of Mental Disorders-IV-Text Revision, the nicotine withdrawal syndrome is characterized by the presence of four out of eight of the following symptoms within 24 hours of "abrupt cessation of nicotine use, or reduction in the amount of nicotine used": depressed mood, sleep disturbance, irritability, anxiety, difficulty concentrating, restlessness, decreased heart rate, and increased appetite. ${ }^{15}$ In some patients the intensity of signs and symptoms associated with withdrawal syndrome are so intense that they need all the pharmacological and behavioral support to successfully quit smoking. As a consequence, doctors play a central role in the treatment of these symptoms and in advising patients about the best way to cope with them. ${ }^{16}$

\section{The physician and smoking cessation}

The Agency for Health Care Policy and Research Guideline on Smoking Cessation strongly encourages physicians to discuss smoking cessation with patients at every visit and offer them medications (if needed) and advice for each quit attempt. ${ }^{17}$ This is because smoking is the main risk factor for a host of diseases, including lung cancer, ischemic heart disease and COPD (chronic obstructive pulmonary disease). Recognizing and dealing with nicotine addiction should not only be a routine component of medical care, but it should rank as one of the highest priorities.

Like other chronic conditions (e.g. hypertension, diabetes and asthma), tobacco dependence is frequently not cured by a single short-term pharmacological intervention and more commonly requires repeated, and sometimes longer-term (i.e. $>3$ months) interventions. More intensive behavioural interventions and combination of pharmacotherapies improve smoking cessation outcomes. ${ }^{18,19}$ Any doctors and health professionals have experienced the frustration of having a patient resume smoking after quitting. Yet they must realize that smoking has a high risk of relapse. Most smokers require more than two serious quit attempts before they abstain forever, and $22 \%$ report three to five quit 
attempts. ${ }^{20}$ Most programs can achieve only 25-30\% long-term abstinence rates, but the health benefits for that $30 \%$ are substantial. Therefore doctors have to be prepared to reassess and treat the smoker on a repeated basis. Also, just as we do not treat all hypertensive or diabetic patients with identical regimens, we should not try to take the same approach with each smoker. If a patient has resumed smoking and wants to quit again, the old plan needs modification. ${ }^{16}$

Smoking cessation at all ages is associated with substantial improvements in life expectancy as well as in quality of life. Interventions (both pharmacological and behavioral) at all levels of intensity are very costeffective. ${ }^{17}$ Nevertheless, the evidence available suggests that management of nicotine addiction receives very little emphasis in many medical schools, and that this lack of training can result in reluctance or in an inadequate approach to dealing with smoking in clinical practice.

In many Latin America countries, health professionals in general and doctors in particular, fail to be proactive in promoting smoking cessation: they do not motivate their patients, offer options for quitting smoking or help prevent smoking initiation among adolescents. This reluctance clearly signifies lost opportunities in the fight against smoking. Given that about $70 \%$ of smokers seek medical assistance over the course of a year due to problems both related and unrelated to smoking, the percentage of wasted possibilities remains significant. This may occur because physicians feel insecure in addressing the various problems when communicating with smokers. ${ }^{20}$

Practically all physicians recognize the hazards of smoking, but they do not usually offer advice on the subject, which represents a missed opportunity for health promotion. ${ }^{21,22}$ In the US, about a third of doctors do not ask their patients about smoking, around $81 \%$ of smokers do not receive assistance, and less than $2 \%$ receive pharmacotherapy. ${ }^{23}$ These findings are probably also common in many other countries, and methods for improving the adherence of all doctors to smoking cessation guidelines are necessary, even in countries such as the US where several states have adopted a rigid stand against tobacco use. ${ }^{24}$

\section{The road to change}

A substantial change in the way professional care-providers think is needed, and the following is required:

- To ensure that doctors and other health workers are equipped with the knowledge and skills they need to deliver smoking cessation interventions in their daily practice.

- To reduce the prevalence of smoking in doctors and, in general, in health care workers.

- To encourage doctors to take the leadership in tobacco control.

The morbidity and mortality related to tobacco can be diminished if a considerable part of the smoking population quits smoking. To reach this objective, all categories of health care professionals, especially doctors, must take part in the fight against smoking, as they have frequent contact with smokers and their influence on patients is well recognized. ${ }^{20}$

\section{Smoking and smoking-related knowledge among physicans}

Smoking among doctors and medical students is a problem worldwide. ${ }^{25-27}$ Smoking rates among physicians are steadily declining, although at different rates in different countries. In the US, around 40\% of doctors smoked in 1959 , and less than $10 \%$ did so by the mid-1990s. ${ }^{27}$ The prevalence of current smoking among Mexican physicians varies according to the survey, with prevalence found between $14-43 \% .{ }^{28-32}$ In general, a higher prevalence was found among men compared with women, and prevalence was higher among physicians than nurses. Surveys indicated that physicians were well informed of the relationship between cigarette smoking and lung cancer and other diseases, like COPD and cardiovascular diseases. Nevertheless this knowledge did not impact the prevalence of smoking. In one of the first surveys (1997) ${ }^{28}$ over 80\% considered tobacco an addictive drug but only $65 \%$ were in favor of banning smoking from their workplaces and over $10 \%$ were not aware that it was forbidden to smoke inside health care facilities. ${ }^{28}$ In general, the prevalence of smoking among physicians in Latin America is similar or in some cases higher ${ }^{32}$ than in the general population. Most of the surveys concluded about the urgent need to design educational programs directed specifically to physicians to decrease this addiction.

Smoking behavior among medical students has been the target of various studies. The World Health Organization (WHO), Centers for Disease Control and Prevention (CDC), and the Canadian Public Health Association (CPHA) developed the Global Health Professional Survey (GHPS) in 2004 to collect data on tobacco use and cessation counseling among health professional students. This is a school-based survey of third year medical students. During 2006, it was carried out in 27 public medical and dental schools in Mexico to asses 
smoking prevalence, knowledge and attitudes about tobacco use and its prevention. A $33.3 \%$ and $43.6 \%$ of medical and dental students reported they are currently smokers. About 8 in 10 students were exposed to second hand smoke and were in favor of banning smoking from their workplaces. Only 22\% received some type of training to treat their patients for smoking cessation and 9 in 10 students will be happy to get this information. About their role in smoking control, 7-8 in 10 students reported that they thought health professionals should play a role in counseling patients about tobacco-cessation programs. The high smoking prevalence found among medical and dental students suggests a strong need for tobacco cessation services and campaigns to help them to quit smoking and training to help their patients. ${ }^{33}$

\section{Smoking cessation advice}

When a doctor smokes, this behavior is reflected in his attitude toward other smokers. In a public survey realized by Harris Interactive in collaboration by Pfizer, ${ }^{34}$ 2863 general doctors from 16 countries and 2510 smokers from 10 countries were included in the SUPPORT (Smoking: Understanding People's Perceptions, Opinions and Reactions to Tobacco) and STOP (Smoking: the Opinion of Physicians) studies. The STOP survey evaluated attitudes, perceptions and habits of both smoking and non-smoking physicians, while the SUPPORT survey assessed attitudes, perceptions and habits of smokers, both of those who had tried to quit smoking and of those who wanted to quit but had never tried. The questions to be analyzed in both surveys were: a) whether physicians and smokers have good communication about their habit, the quality of communication between doctors and smokers about smoking and $b$ ) what physicians and smokers perceive as necessary to improve smoking cessation rates. One of the main findings of these surveys was that smoking cessation is believed to be extremely important, but also extremely difficult. There is also a serious communication gap between doctors and patients, and this is perceived as a hindrance to receiving the support needed to help them achieve smoking cessation. ${ }^{34}$

The studies identified a number of barriers in Mexico that hindered communication between doctor and patient, and, therefore, prevented smokers from receiving advice about quiting smoking. It was observed that a significant percentage of physicians and smokers believe doctors do not have time to provide stop-smoking advice to their patients who smoke, or else they had other priorities or were poorly trained to help patients quit smoking. Furthermore, physicians who smoked showed lower interest in smoking cessation and were less interested in helping their patients to quit. ${ }^{34}$ Studies in other countries have found that ${ }^{35}$ physician's negative attitudes towards discussing smoking cessation with patients include: it was too time-consuming $(42 \%)$, not effective $(38 \%)$, no confidence in ability $(22 \%)$, unpleasant experience $(18 \%)$, and low confidence in knowledge $(16 \%)$

Generally, this non-interventionist attitude toward smoking during routine visits is attributed to the physician's lack of time. Patients share this perception that their doctor has more important matters to discuss in relation to their health. As a results, smoking becomes a secondary preoccupation. This is a serious aspect of the problem, because physicians have an obligation to promote healthy attitudes and behaviors. ${ }^{20}$

Physicians' lack of confidence about providing cessation advice can be credited, at least in part, to insufficient specific training. However, this may be reinforced by the belief that smoking cessation is not the doctor's responsibility, but a decision that only the smoker must make. Physicians should recognize their role to provide adequate information about the hazards of tobacco, presented in a clear and objective manner, and, to the extent possible, directed at the specific clinical situation of each smoker. In addition, doctors should encourage as many patients as possible to utilize available and scientific recognized treatments. ${ }^{20,22}$

\section{Training around smoking and smoking cessation}

A study involving 1353 medical schools in 143 countries revealed that only $11 \%$ included knowledge about how to handle smoking-related problems, of which $64 \%$ addressed the topic of nicotine dependence and only 30\% discussed treatment and cessation methods. Although curricula in the majority of the schools covered various clinical aspects of tobacco-related diseases, these aspects were not passed on to students in a systematic or integrated manner that would have allowed for discussion of tobacco cessation. ${ }^{20,35}$

Among the different barriers against implementing tobacco cessation curricula are: the teachers have limited knowledge in this area; resources for teaching are extremely limited; there is a lack of interest by academic/clinical staff in teaching this topic; lack of time for introducing a new topic into an established and full medical curriculum; lack of incentives or advantages to teach about tobacco; and limited organizational ability within medical school to include new subjects. In many countries the structure of medical curriculum is not flexible enough to introduce new topics. ${ }^{36}$

The findings revealed that medical students generally have poor knowledge of smoking as a major cause of 
diseases. ${ }^{37-39}$ The deficiencies in knowledge among medical students reflect a general failure of medical schools globally to teach about tobacco in the curriculum. These findings raise the issue that, if medical students are to become effective agents for reducing smoking when they graduate, then more efforts need to be directed toward increasing basic knowledge of tobacco-related diseases in the medical curriculum. ${ }^{39}$

Medical schools have a critical opportunity to educate and motivate emerging doctors and should be encouraged to include teaching about tobacco issues in their curricula. Furthermore, teachers should present strong non-smoking models. Without adequate education in tobacco, doctors of the future will be unable to fulfill their important role in tobacco prevention and control. Yet medical practitioners are more likely to intervene and to achieve higher smoking cessation rates if they receive adequate training in intervention techniques and counseling. ${ }^{37}$

There are several programs for teaching medical students about tobacco and smoking cessation intervention skills. Most of them have been developed and evaluated in industrialized countries and written in English but some of them, like the Smokescreen Education Program, are currently being translated into other languages. ${ }^{40}$

Knowledge in basic and clinical science related to tobacco use, attitudes and behaviours are minimal skills that should comprise core graduation requirements for medical students. Among the basic science topics to cover are: ${ }^{20,40,41}$ cancer risk from tobacco; health effects: tobacco-related diseases; cigarette smoke constituents; nicotine withdrawal symptoms; high-risk groups with most difficulty quitting (teenagers, pregnant women, psychiatric disorders). Clinical science topics include: clinical intervention to promote cessation; relapse prevention; pharmacological agents; smoking cessation techniques in artificial settings; smoking cessation techniques in clinical settings with patients; smoking cessation techniques in clinical settings with patients and evaluation performance.

\section{Conclusions}

Some progress has been achieved in smoking control, but much remains to be done, especially in developing countries. As an example, in the program of the World Congress of Cardiology held in Buenos Aires in 2008, with more than 3000 worldwide participants and hundreds of activities, only one session addressed the problem of tobacco treatment. This is amazing since cardiovascular specialists could be leaders in smoking prevention and treatment because cardiovascular disease (CVD) persists as the leading cause of death worldwide and the CVD burden is predicted to increase due to aging of the population and of unhealthy lifestyles, including the increase in smoking prevalence.

Today, effective tobacco dependence treatment regimens exist for which guidelines are widely available. Government agencies, health care organizations, clinicians and scientists are working hard to obtain even better results, and health care providers, especially physicians, must join these efforts. Assessing each patient's use of tobacco and ensuring access to smoking cessation counseling and pharmacotherapy are a necessary component of this effort. For these strategies to become fully effective, we need to overcome physicians' reluctance to assume a proactive role in the care of smokers. ${ }^{20}$

Doctors have played a key role in the identification of tobacco as the leading cause of preventable disease, and in providing care for those who suffer from its devastating consequences. In Latin America we must overcome the missed opportunity to teach students in medical school how to talk to smokers about quitting. We must change physicians' attitude and behaviors about smoking. The time has come for physicians to become the leaders in the fight against smoking in the $21^{\text {st }}$ century, otherwise we could lose this unique opportunity.

\section{Declaration of conflicts of interest}

I declare that I have no conflicts of interest.

\section{References}

I. Hensley T. Smoking and Health in the Americas. [Accessed 12 March, 1992]. Available at: http://www.hhs.gov/news/press/ prel995pres/920312a.txt

2. Organización Mundial de la Salud. OMS. MPOWER: Un plan de medidas para hacer retroceder la epidemia de tabaquismo. Ginebra: OMS, 2008. 3.World Health Organization. International Statistical Classification of Diseases and Related Health Problems. Tenth Revision. ICD- I0. Geneva: WHO, 2004.

4.American Psychiatric Association. Diagnostic and Statistical Manual of Mental Disorders IV.Text Revision. 2000.

5. US Department of Health and Human Services. The health consequences of smoking. Nicotine addiction. A report of the Surgeon General.Atlanta GA. DHHS Publication No. (PHS) (CDC) 88-8406, 1988. 6. . Fiore MC, Bailey WC, Cohen SJ. Treating tobacco use and dependence. US Department of Health and Human Services. Washington: Clinical Practice Guideline, 2000.

7. Berrettini W. Nicotine addiction. Am J Psychiatry 2008 I65;9:I089-I092. 8. Rose EJ, Behm MF,Westman CE, Mathew JR, London DE, Hawk CT, et al. PET Studies of the Influences of Nicotine on Neural Systems in Cigarette Smokers. Am J Psychiatry 2003; 160:323-333. 
9. Tapper AR, McKinney SL, Nashmi R. Nicotine activation of $\alpha_{4}$ receptors: sufficient for reward, tolerance, and sensitization. Science 2004; 306 : 1029-1032.

10. Perry CD, Davila-Garcia M, Stockmeier CA, Kellar JK. Increased Nicotinic Receptors in Brains from Smokers: Membrane Binding and Autoradiography Studies.J Pharmacol Exp Ther 1999; 289: 1545-I552. II. Balfour DJK. The neurobiology of tobacco dependence: a preclinical perspective on the role of the dopamine projections to the nucleus accumbens. Nicotine Tob Res 2004; 6: 899-912.

12. Kelley AE. Nicotine receptors: addiction's smoking gun? Nat Med 2002; 31: 447-449.

13. Foulds J.The neurobiological basis for partial agonist treatment of nicotine dependence: varenicline. Int J Clin Pract 2006; 60(5): 57I-576. 14. Goldstein ZR, Volkow N. Drug addiction and its underlying neurobiological basis: neuroimaging evidence for the involvement of the frontal cortex. Am J Psychiatry 2002; 159:1642-1652.

15. Hughes RJ, Hatsukami D. Signs and symptoms of tobacco withdrawal. Arch Gen Psychiatry 1983; 43: 289-294.

16. Dale CL. Tailoring smoking cessation to your patients needs.J Respir Dis 1998; 19(8): S43-S49.

17. U.S. Department of Health and Human Services. The health Benefits of Smoking Cessation. US Department of Health and Human Services. Public Health Service. Centers for Disease Control. Center for Chronic Disease Prevention and Health Promotion. Office on Smoking and Health. DHSS Publication No.(CDC) 94-84I6, 1990.

18. Hall SM, Humfleet GL, Reus VI, et al. Extended nortriptyline and psychological treatment for cigarette smoking.Am J Psychiatry 2004; 161: 2100-2107.

19. Foulds J, Gandhi KK, Steinberg MB et al. Factors associated with quitting smoking at a tobacco dependence treatment clinic. Am J Health Behav 2006; 30: 400-4I2.

20. Chatkin J, Chatkin G. Learning about smoking during medical school: care we still missing opportunities? Int J Tuberc Lung Dis 2009; 13(4):429-437

21. Fiore M C, Epps R P, Manley MW.A missed opportunity. Teaching medical students to help their patients successfully quit smoking.JAMA 1994; 27I: 624-626

22. Saloojee Y, Steyn K. Educating medical students about tobacco. S Afr Med J 2005; 95: 330-331.

23. Ferketich A K, Khan Y,Wewers ME. Are physicians asking about tobacco use and assisting with cessation? Results from the 200I-2004 national ambulatory medical care survey (NAMCS). Prev Med 2006; 43: 472-476.

24. Fiore M C, Croyle R T, Curry S J, Cutler MC, Davis MR, et al. Preventing 3 million premature deaths and helping 5 million smokers quit: a national action plan for tobacco cessation. Am J Public Health 2004; 94(2):205-210.

25. Nerín I, Guillén D, Mas A, Crucelaegui A. Evaluation of the influence of medical education on the smoking attitudes of future doctors. Arch Bronconeumol 2004; 40: 34I-347.
26. Senol Y, Donmez L, Turkay M,Aktekin M. The incidence of smoking and risk factors for smoking initiation in medical faculty students: cohort study. BMC Public Health 2006; 6: 128.

27. Smith D R, Leggat $P A$. An international review of tobacco smoking in the medical profession: 1974-2004. BMC Public Health 2007; 7: I I2-I I5. Available at: http://www.biomedcentral.com/content/pdf//47/-2458-7II5.pdf

28. Tapia-Conyer R, Cravioto P, De la Rosa B, Galván F, García-de la Torre G, Kuri P. Cigarette smoking; knowledge and attitudes among Mexican physicians. Salud Publica Mex 1997;39:507-5 I2.

29. Sansores R, Villalba-Caloca J, Herrera- Kiengelher L, Soriano-Rodríguez A, Ramírez-Venegas A. Prevalencia de tabaquismo en empleados de los Institutos Nacionales de Salud en México. Salud Publica Mex 1999;41: 38I-388.

30. Sansores RH. Tabaquismo en médicos mexicanos: un análisis comparativo con fumadores que no son médicos. Rev Invest Clin 2000; 52(2):161-167.

31. Salmerón-Castro J,Arillo-Santillán E, Campuzano-Rincón JC, LópezAntuñano FJ, Lazcano-Ponce EC. Tabaquismo y profesionales de la salud del Instituto Mexicano del Seguro Social, Morelos. Salud Publica Mex 2002;44 supl I:S67-S75.

32. Minervini CD, Zabert EG, Rondelli PPM, Gómez M, Castaños C, Buist $\mathrm{SA}$, et al. Tobacco use among Argentine physicians: personal behavior and attitudes. Rev Arg Med Resp 2006;(3): 100-105.

33. Reynales-Shigematsu LM,Vázquez-Grameix JH, Lazcano-Ponce E. Encuesta mundial de tabaquismo en estudiantes de la salud, México 2006. Salud Publica Mex 2007;49 supl 2:S194-S204.

34. Pfizer- SUPPORT (Smoking: Understanding People's Perceptions, Opinions and Reactions to Tobacco) and STOP (Smoking: the Opinion of Physicians) studies. México: Press Release, 2007.

35. Vogt F, Hall S, Marteau TM. General practicioners' and family physicians' negative beliefs and attitudes towards discussing smoking cessation with patients: a systematic review. Addiction 2005; 100: |423- I43I.

36. Richmond R, Taylor R. Global dissemination of a tobacco curriculum in medical schools. Int J Tuberc Lung Dis 2006; 10: 750-755.

37. Crofton J,Tessier JF.A worldwide survey of knowledge and attitudes of tobacco among medical students. In: Richmond R, ed. Educating medical students about tobacco: planning and implementation. Paris: International Union Against Tuberculosis and Lung Disease, 1997: 27I-280.

38. Tessier JF, Freour PP, Belougne D. Smoking habits and attitudes of medical students towards smoking and anti-smoking campaigns in nine Asian countries. Int J Epidemiol 1992; 21:298-304.

39. Richmond R, Debono SD, Larcos D, Kehoe L. Worldwide survey of education on tobacco in medical schools. Tobacco Control 1998; 7:247-252 40. Richmond R. Teaching medical students about tobacco.Thorax 1999 54: 70-78.

41. Spangler J G, George G, Foley K L, Crandall S J.Tobacco intervention training: current efforts and gaps in US medical schools. JAMA 2002; 288: 1102-1109. 